\title{
UNIVERSITY OF WASHINGTON DATES IV
}

\author{
A W FAIRHALL, A W YOUNG, and J L ERICKSON
}

Department of Chemistry, University of Washington, Seattle, Washington 98195

The dates reported in this list are for geologic and archaeologic samples only. During the interval since our last date list (R, 1966, v 8, p 498-506) most of our measurements have been on samples of sea water. These will be reported separately at a later time. The methods used are essentially those reported previously (R, 1963, v 5, p 80-81) but with the following notable changes and additions: We now prepare our methane counting gas as described in Buddemeier et al (1970). Our 1L membrane counter has since been augmented by 3 additional counters. Two of these are $1 \mathrm{~L}$ quartz proportional counters inside geiger anticoincidence shields. Operating pressures are ca 1.5 to $4 \mathrm{~atm}$. Backgrounds of these 2 counters are in the neighborhood of 1.8 and $3 \mathrm{cpm}$ and the net counting rate of NBS oxalic acid ranges from 7 to $18.7 \mathrm{cpm}$, depending on the pressure. The third counter ("minicounter") is rather special: a $.1 \mathrm{~L}$ quartz proportional counter inside a methane proportional anticoincidence counter. Sample and anticoincidence counting gases are introduced simultaneously with a differential pressure that never exceeds a few $\mathrm{cm} \mathrm{Hg}$. The sample filling side is constructed so as to minimize dead volume; over $80 \%$ of the sample gas is inside the active volume of the ${ }^{14} \mathrm{C}$ counter. The range of filling pressures which are possible is ca 1 to $4 \mathrm{~atm}$.

Samples with as little as $.1 \mathrm{~g}$ of carbon were measured using this counter. Several samples reported in this date list were measured with it, being particularly useful for samples with $<\lg$ of datable carbon. The counting rate is very stable, a necessary condition for the weeklong counting periods required for old samples. The background counting rate is very slightly pressure-dependent. At 4atm filling pressure it is $0.290 \pm 0.005 \mathrm{cpm}$. The corresponding net counting rate of NBS oxalic acid at this filling pressure is $2.260 \pm 0.020 \mathrm{cpm}$. The outer walls of the counter are stainless steel, and the shielding consists of $3 \mathrm{~cm}$ mercury and $14 \mathrm{~cm}$ ordinary steel. All electronics are housed on top of the shield inside a faraday cage.

All $4{ }^{14} \mathrm{C}$ counters are automatically scaled for $10 \mathrm{~min}$ and the counts read out onto punched paper tape. Each day the tape is read into a computer and the data re-recorded onto magnetic tape. Simultaneously the computer is programmed to make chi squared tests on the $10 \mathrm{~min}$ counts to reject any results which fail to satisfy Chauvenet's criterion, (which seldom happens and then only for a datum which barely falls outside the criterion limit), to compute average counting rate and standard deviation, and print out all these data. Ages are calculated from the net counting rate using $5568 \mathrm{yr}$ for the radiocarbon half-life. 


\section{SAMPLE DESCRIPTIONS}

\section{ARCHAEOLOGIC SAMPLES}

\section{A. Southern Africa}

\section{Nelson Bay Cave series, South Africa}

Nelson Bay Cave $\left(34^{\circ} 6^{\prime} 10^{\prime \prime} \mathrm{S}, 23^{\circ} 22^{\prime} 30^{\prime \prime} \mathrm{E}\right)$ is on the Robberg Peninsula at Plettenberg Bay, ca $500 \mathrm{~km}$ E of Cape Town, South Africa. Excavations were started in 1965-66 by $\mathrm{R} R$ Inskeep and continued by R G Klein and R R Inskeep in 1971-72. A 2m sequence of Middle Stone age levels is overlain unconformably by $6 \mathrm{~m}$ of Later Stone age. UW-224, -223 , and -290 date successively lower Middle Stone age horizons, but are considerably more recent than dates on comparable materials elsewhere, eg, at the Kalasies River Mouth caves (Klein, 1974a). In the absence of easily identifiable charcoal, patches of darkish sediment were chosen for dating and contamination is likely. UW-175 dates earliest Later Stone age occupation in the cave, belonging to the Robberg industry. It agrees with GrN-5884: 18,660 \pm 110 (unpub) on the same level and with I-6516: $16,700 \pm 240$ (unpub) on a slightly higher Robberg horizon. UW-218, $-177,-162,-164$, and -178 are on successively higher levels of the Albany industry which overlies the Robberg industry at the site. Although UW-218 is out of sequence, the dates agree well with I-6515: $10,080 \pm 260$, Pta-392: $10,150 \pm 90$, and O-1085: 10,256 \pm 210 (unpub) which are on the same levels as UW-177, -164, and -178 , respectively. Faunal remains accompanying the Albany industry include shells and bones of marine creatures, making their first appearance in the cave in the lowermost Albany horizons. The last appearance of some now extinct large mammals is also recorded in the lowermost Albany levels. UW-184, -181, -179, -222, -187, -176, -186, -216, and -217 date successively higher levels of Wilton industry which closes out the sequence at Nelson Bay. The Nelson Bay cultural sequence and fauna have been discussed by Klein (1972a, b; 1974a, b), sediments by Butzer (1973). An earlier date list may be found in Fairhall and Young (1973). Coll and subm 1970-73 by R G Klein.

$\begin{array}{lc}\text { UW-162. Nelson Bay Cave } & \mathbf{1 1 , 5 0 5} \pm \mathbf{1 1 0} \\ \text { Charcoal from Level CS. } & \mathbf{9 6 5 5} \mathbf{B C} \\ & \mathbf{1 0 , 1 8 0} \pm \mathbf{8 5} \\ \text { UW-164. Nelson Bay Cave } & \mathbf{8 2 3 0} \mathbf{B C} \\ \text { Charcoal from hearth, Level CS. } & \\ & \mathbf{1 8 , 1 0 0} \pm \mathbf{5 5 0} \\ \text { UW-175. Nelson Bay Cave } & \mathbf{1 6 , 1 5 0 ~ B C} \\ & \delta^{13} C=-27.3 \%\end{array}$

Fine charcoal in carbonaceous earth from base of Level YGL. 


\section{UW-176. Nelson Bay Cave}

Charcoal from brown soil, Level BSBI.

\section{UW-177. Nelson Bay Cave}

Charcoal from brown soil, Level GSL.

UW-178. Nelson Bay Cave

Soil from Level BSBJ.

\section{UW-179. Nelson Bay Cave}

Shell (Patella) at top of Level RA.

\section{UW-181. Nelson Bay Cave}

Charcoal from interface of Levels J and RB.

\section{UW-184. Nelson Bay Cave}

Shell (Patella) from interface of Levels J and RB.

UW-186. Nelson Bay Cave

Charcoal from brown soil, Level BSBI.

UW-187. Nelson Bay Cave

Fine charcoal in soil from Level BSBH.

UW-216. Nelson Bay Cave

Charcoal, Level H/G.

UW-217. Nelson Bay Cave Shell (Patella), Level I.

UW-218. Nelson Bay Cave

Charcoal from interface of Levels YSL and BSL.

UW-222. Nelson Bay Cave

Finely divided charcoal in soil matrix.

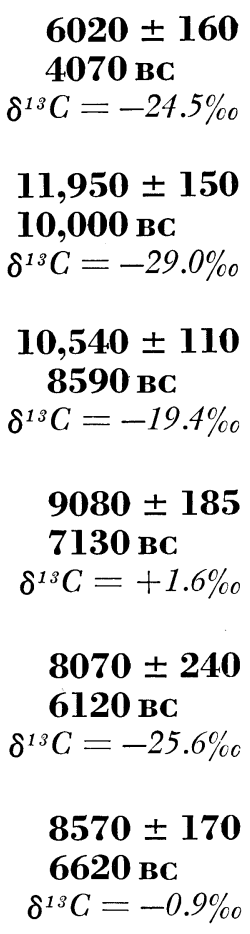

$6050 \pm 80$ $4100 \mathrm{BC}$ $\delta^{13} C=-24.8 \%$ $5825 \pm 150$ 3875 BC

$5830 \pm 115$ 3880 вС

$4860 \pm 65$ 2910 BC

$10,600 \pm 150$

8650 BC

$6070 \pm 125$

$4120 \mathrm{BC}$

$\delta^{13} C=-24.3 \%$ 


\section{UW-223. Nelson Bay Cave}

Charcoal from black loam, MSA SPIT 10.

\section{UW-224. Nelson Bay Cave}

Carbonaceous sediment from MSA SPIT 8.

UW-290. Nelson Bay Cave

Brown soil from MSA SPIT 10.

$$
24,120 \pm 660
$$

22,170 BC

$\delta^{13} \mathrm{C}=-25.0 \%$

$17,600 \pm 195$

15,650 вC

$22,400 \pm 340$

20,450 BC

\section{Hoffman's Cave series, South Africa}

Hoffman's Cave (=East Ghwanogat) $\left(34^{\circ} 6^{\prime} \mathrm{S}, 23^{\circ} 22^{\prime} \mathrm{E}\right)$ is ca $300 \mathrm{~m}$ E of Nelson Bay Cave on the Robberg Peninsula, Plettenberg Bay, South Africa. A C Hoffman excavated a trench ca $1.5 \mathrm{~m}$ wide and $5 \mathrm{~m}$ long through roughly $2 \mathrm{~m}$ of Later Stone age shell midden and recovered numerous human remains, animal bones, and artifacts (all unpub). The trench bottomed out on sterile sand. In 1970, R G Klein attempted unsuccessfully to determine what, if anything, lay below the sand, which is a minimum of $3.5 \mathrm{~m}$ thick. UW-205 and -204 date bottom and top, respectively, of the Later Stone Age midden sequence in trench. Contents of a balk sample removed from the site in 1970 were reported by H J Deacon (1972, 1974). Subm 1971 by R G Klein.

\section{UW-204. Hoffman's Cave}

Shell (Patella) from top of midden.

\section{UW-205. Hoffman's Cave}

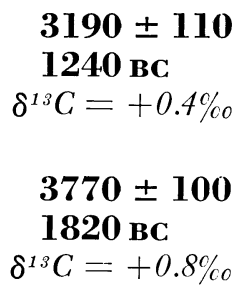

Shell (Patella) from bottom of midden, over massive sandy base.

\section{Elandsbay Cave series, South Africa}

Elandsbay Cave $\left(32^{\circ} 30^{\prime} \mathrm{S}, 18^{\circ} 30^{\prime} \mathrm{E}\right)$ is ca $160 \mathrm{~km} \mathrm{~N}$ of Cape Town on the Atlantic Coast of South Africa. Excavations were conducted in 1970 and 1972 by J E Parkington (1972). UW-193 and -192 date successively higher levels of the Albany industry within the cave, containing, among other things, the latest known occurrence of the giant Cape Horse (Equus capensis). They agree well with Pta-737: 10,700 \pm 100, -732: 10,640 \pm 110 , and $-686: 9600 \pm 90$ (unpub), also on successively higher Albany horizons within the cave. Subm 1971 by R G Klein.

\section{UW-192. Elandsbay Cave}

$$
\begin{gathered}
11,070 \pm 140 \\
9120 \text { BC } \\
\delta^{13} C=-23.4 \%
\end{gathered}
$$

Charcoal from Level 6 (bottom). 


\section{UW-193. Elandsbay Cave}

Charcoal from Level 6 (middle).

\section{Melkhoutboom Cave series, South Africa}

Melkhoutboom Cave $\left(33^{\circ} 19^{\prime} \mathrm{S}, 25^{\circ} 17^{\prime} \mathrm{E}\right)$ is in the Cape Folded Mts, ca $75 \mathrm{~km}$ NE of Porth Elizabeth, South Africa. Excavations were conducted in 1967 and 1969 by H J Deacon. UW-233 dates earliest occupation of cave, assigned to Robberg industry. UW-234 is on the lowermost Wilton level at the site. The dates are in proper sequence; a series of GaK and Pta dates discussed by Deacon (1969, 1972, 1974). Subm 1971 by R G Klein.

\section{UW-233. Melkhoutboom Cave}

Charcoal from basal unit.

\section{UW-234. Melkhoutboom Cave}

Charcoal from Wilton Base Marker.
$15,400 \pm 120$

13,450 вC

$$
7290 \pm 80
$$

\section{Boomplaas Cave A series, South Africa}

Bloomplaas Cave A $\left(33^{\circ} 23^{\prime} \mathrm{S}, 22^{\circ} 11^{\prime} \mathrm{E}\right)$ is in $\mathrm{mts}$ of the Cape Folded Belt, ca $30 \mathrm{~km} \mathrm{~N}$ of Oudtshoorn, Cape Province, South Africa. UW-307 dates a late Wilton level with pottery and sheep remains. UW336 is on a lower Wilton level with sheep but no pottery. UW-306 is on a yet earlier, pre-pottery, pre-sheep Wilton level. UW-301 is on an early Albany industry level. UW-300, $-304,-305$, and -308 are on successively lower horizons with, as yet, undescribed cultural materials. In combination with artifactual, faunal, and sedimentologic data, available dates indicate that Boomplaas Cave A contains the longest continuous or near continuous Upper Pleistocene/Holocene sequence discovered in South Africa. Excavation was started in 1974 and continues under the over-all direction of H J Deacon. Subm 1974 by R G Klein.

UW-300. Boomplaas Cave A

$21,110 \pm 420$

Charcoal dust in soil matrix from Level AF1LP.

$$
19,160 \mathrm{BC}
$$

UW-301. Boomplaas Cave A

$14,200 \pm 240$

Charcoal from Level CL.

UW-304. Boomplaas Cave A

$32,400 \pm 700$

Charcoal in soil matrix from Level BPBH.

$30,450 \mathrm{BC}$

$>40,000$

UW-305. Boomplaas Cave A

Charcoal from Level OLP1. 
UW-306. Boomplaas Cave A

$6400 \pm 75$

Charcoal from Level AF1 BRL.

4450 BC

UW-307. Boomplaas Cave A

Charcoal from Level BLD.

UW-308. Boomplaas Cave A

Charcoal dust in soil matrix from Level P12BOL.

$1510 \pm 75$

AD 440

UW-336. Boomplaas Cave A

Charcoal from BLD AM-AF/P18.

UW-337. Boomplaas Cave A

Charcoal from AF-DGL/L13.

UW-338. Boomplaas Cave A

Charcoal from BLD 2/I14.

$1955 \pm 65$

5 BC

$1630 \pm 50$

AD 320

$1700 \pm 50$

AD 250

\section{Saldanha Bay series, South Africa}

The Sea Harvest Middle Stone age shell midden is at Saldanha Bay, South Africa $\left(33^{\circ} \mathrm{S}, 18^{\circ} \mathrm{E}\right)$. Dates were expected in view of $\mathrm{K} W$ Butzer's ( $m$ s in prep) tentative geologic evaluation of midden age as later Last Interglacial. The Sea Harvest Middle Stone age shell midden and others around Saldanha Bay are the oldest open-air shell middens discovered anywhere in the world. Coll and subm 1973 by R G Klein.

UW-282. Sea Harvest midden

$>40,000$

Ostrich egg shell picked from mixed ostrich egg and Patella shells.

UW-292. Sea Harvest midden

Ostrich egg shell.

$>40,000$

\section{UW-291. Die Kelders Cave I, South Africa}

$1570 \pm 55$

Charcoal from Die Kelders Cave I ca 160km ESE of Cape Town on $S$ coast of South Africa (34 $32^{\prime}$ S, $19^{\circ} 22^{\prime}$ E). Dates a Later Stone age horizon with earliest sheep remains recovered at the site (Schweitzer \& Scott, 1973; Schweitzer, 1974). Date is in proper sequence with a series of GX and GaK dates indicating that entire Later Stone age occupation at Die Kelders I falls within the 1 st $500 \mathrm{yr}$ AD (Schweitzer, 1970). Coll 1970 and subm by R G Klein.

\section{UW-287. Gansbaai, South Africa}

$10,570 \pm 85$

Pulverized charcoal in sand from Byeneskranskop

$\left.19^{\circ} 28^{\prime} \mathrm{E}\right)$, a $160 \mathrm{kcoal}$ in sand from Byeneskranskop Cave I $\left(34^{\circ} 35^{\prime} \mathrm{S}\right.$,

$\left.19^{\circ} 28^{\prime} \mathrm{E}\right)$, ca $160 \mathrm{~km}$ ESE of Cape Town, near Gansbaai, South Africa. Sample from a level containing artifacts belonging to the Later Stone 
age Albany industry. It is in sequence with I-7948: 12,730 \pm 185 (unpub) on a somewhat lower Albany horizon. Excavation was started 1973 by F R Schweitzer and continues. Subm by R G Klein.

\section{B. Northern Africa}

\section{Ahaggar series, Algeria}

The Ahaggar massif rises in S region of Algerian Sahara above vast lowlands all around, particularly toward $\mathrm{W}$ and S. It was mainly formed, at its center, by huge volcanic formations of all kinds, surrounded by granitic chains where most archaeologic sites appear. Geologic formations are sometimes more varied on its ledges, with particularly long plateaus of sandstone, "Tassili". Roughly between $1^{\circ}$ and $10^{\circ} \mathrm{E}, 20^{\circ}$ and $27^{\circ} \mathrm{N}$, it is crossed by the Tropic of Cancer and, thus, has a tropical climate, ranging from dry lowlands to wetter and grassy summits.

This massif was, for a long time, almost totally unknown to archaeologists. Only a few studies were made between 1940 and $1960, i e$, those by $\mathrm{H}$ Lhote, and mainly $\mathrm{H} \mathrm{J}$ Hugot, who worked in the NW area. By 1963 J P Maître made the 1st surveys and excavations in the Atakôr and Tefedest ranges, the heart of the massif. Ten yr of field work and analysis led to the hypothesis that 2 main Neolithic cultures occupied the central region from ca 9000 to 2000 BC (Maître, 1971, 1974, 1975). The oldest is the Timidouin culture, or Mountain Neolithic, and is supposedly from late Paleolithic levels, 10th millennium BC; it is found in all the highlands, chiefly in the Tefedest range and the N Atakôr. The other, the Amekni culture, seems more recent and diffused into the rolling country beneath the mts; it is probably an evolved stage of Sudanese tradition Neolithic.

Of the following radiocarbon dates, UW-87 is related to lower phase Amekni culture; UW-96 and -97, probably to Timidouin culture. The others (UW-88, -89, -93, -95) derive from archaeologic levels of S Atakôr, where confusion still exists; it seems here that an Amekni influence reached numerous sites of Timidouîn type. Some archaeologists, eg, G Camps (1974), reject these views and attribute findings to only one civilization, "Saharo-Sudanese Neolithic", which filled Sahara with several sub-cultures, differing in each area.

\section{UW-87. Amekni}

$8050 \pm 80$

Charcoal from hearth at $80 \mathrm{~cm}$ depth under collapsed stone shelter in Amekni Wadi valley, ca $40 \mathrm{~km}$ WNW of Tamanrasset $\left(22^{\circ} 53^{\prime} \mathrm{N}, 05^{\circ}\right.$ $14^{\prime}$ E). Charcoal from base of site was dated $8670 \pm 150$ BP (MC-212; R, 1969, v 11, p 127). Other samples from the same site, Gif-464: $5500 \pm$ 250 вP (R, 1970, v 12, p 436) and Gif-1222: $6800 \pm 220$ вР (R, 1972, v 14, p 293) indicate a long occupation. Coll 1965 by J P Maître and G Camps, Inst Sci Humaines en Algérie; subm by W A Fairservis. 


\section{UW-88. Abouleg}

$5090 \pm 80$

3140 вс

Charcoal from site atop small hill on right bank of Aoufayen Wadi $\left(23^{\circ} 39^{\prime} \mathrm{N}, 05^{\circ} 59^{\prime} \mathrm{E}\right)$, depth 15 to $30 \mathrm{~cm}$. Replicate samples dated 5130 \pm 110 (MC-472, unpub) and $4600 \pm 250$ BP (Gif-465; R, 1970, v 12, p 437). Coll 1965 by J P Maître; subm by W A Fairservis.

\section{UW-89. Abouleg}

$6830 \pm 80$

Charcoal from same site as above, depth 30 to $60 \mathrm{~cm}$. Coll 1965 by J P Maître; subm by W A Fairservis.

\section{Tiltekin sub-series}

Discovered in 1961 by M Launey, 5 excavations were made in 1966. The sites are among granitic debris on summit and adjacent slopes of a prominent spur at confluence of Tiltekin and In Daleg Wadis, ca $50 \mathrm{~km}$ NNE of Tamanrasset $\left(23^{\circ} 18^{\prime} \mathrm{N}, 05^{\circ} 45^{\prime} \mathrm{E}\right)$. Coll and subm 1966 by J P Maître.

UW-93. Charcoal

$7090 \pm 90$

From a small barrow at edge of site. Exact relation between this site and the others is unknown.

UW-94. Hearth $\gamma$

$6800 \pm 105$

Charcoal, 25 to $45 \mathrm{~cm}$ depth.

4850 BC

\section{UW-95. Midden $\alpha$}

$5055 \pm 80$

$3105 \mathrm{BC}$

Charcoal from small midden at edge of site. This site appears to be related to the others.

UW-96. Hearth $\beta$

$8475 \pm 100$

Charcoal, 20 to $40 \mathrm{~cm}$ depth. Another sample from 30 to $40 \mathrm{~cm}$ depth dated $7960 \pm 100$ вр (MC-739, unpub).

\section{UW-97. Hearth $\beta$}

$9210 \pm 115$

Charcoal, 40 to $60 \mathrm{~cm}$ depth. Another sample from 50 to $60 \mathrm{~cm}$ depth dated $8900 \pm 230$ вр (MC-740, unpub).

\section{New Guinea}

\section{Kainantu series, Papua, New Guinea}

First archaeologic project directed to discovery and excavation of open sites in the Kainantu subdistrict, Eastern Highlands Dist, Papua, New Guinea. Seventy sites were located, of which 8 were excavated. The bulk of artifacts recovered are stone tools, suggesting a predominantly lithic technology (Watson \& Cole, in press). Coll 1967 by J D Cole, Univ Washington. 


\section{UW-107. Kainantu subdistrict}

$3300 \pm 120$

1350 BC

Charcoal from habitation surface in Site NGG, Unit 1S18W $\left(6^{\circ} 25^{\prime}\right.$ $\left.\mathrm{S}, 145^{\circ} 50^{\prime} \mathrm{E}\right)$ at $+1680 \mathrm{~m}$. Assoc with a few stone tools, but at same level as larger concentrations of artifacts in other secs of site. Subm by W A Fairservis.

\section{UW-108. Kainantu subdistrict}

$3780 \pm 100$ 1830 BC

Charcoal from Type $\mathrm{E}$ hearth (stone-ringed, circular) at Site NGH, Units $2 \mathrm{~S} 5 \mathrm{~W}$ and $2 \mathrm{~S} 6 \mathrm{~W}\left(6^{\circ} 25^{\prime} \mathrm{S}, 145^{\circ} 50^{\prime} \mathrm{E}\right)$ at $+1700 \mathrm{~m}$. Subm by $\mathrm{W}$ Fairservis.

\section{UW-260. Kainantu subdistrict}

$3530 \pm 130$

1580 BC

Charcoal from Site NFB at E edge of Noreikora Swamp $\left(6^{\circ} 24^{\prime} \mathrm{S}\right.$, $\left.145^{\circ} 54^{\prime} \mathrm{E}\right)$. Scatter sample from Level 5, Baulk 16N8W-16N10W, beneath a fragment of stone bowl or mortar at depth $70.5 \mathrm{~cm}$, Level $4 \mathrm{~B}$. Subm by V D Watson.

\section{UW-261. Kainantu subdistrict}

$3060 \pm 70$

Charcoal from Site NFB at E edge of Noreikora Swamp $\left(6^{\circ} 24^{\prime} \mathrm{S}\right.$, $145^{\circ} 54^{\prime}$ E). Sample from Baulk 16N6W-16N8W, Level 4A, above Level 4B. Subm by V D Watson.

\section{UW-262. Kainantu subdistrict}

$11,510 \pm 140$ 9560 вС

Charcoal from Site NFX, $200 \mathrm{~m}$ N of Malaria R $\left(6^{\circ} 39^{\prime} \mathrm{S}, 146^{\circ} 00^{\prime}\right.$ E). Scatter sample from $3 \mathrm{~S} 20 \mathrm{~W}$ assoc with a few stone tools and debitage that lay on culturally sterile soil. Site was occupied intermittently over a long period. Bulk of artifacts, occurring at overlying level were not radiometrically dated. A frequency seriation suggests their similarity to material from Sites NGH and NGG, in decreasing order, and their postdating NGG, although exact dates are undetermined. Subm by V D Watson.

\section{North America}

\section{Enumclaw, Washington series, United States}

The Osceola Mudflow was a massive flow emanating from volcanic activity above $3000 \mathrm{~m}$ on Mt Rainier (Crandell, 1963) previously dated: L-233A, -233B (Science, 1956, v 124, p 158), W-564 (R, 1960, v 2, p 163) at ca 4800 BP. Excavations began in 1968 at the Imhof site, 45 PI44 (47 $\left.12^{\prime} \mathrm{N}, 122^{\circ} 07.5^{\prime} \mathrm{W}\right)$. Subsequently, in 1972 , excavations began at the Jokumsen site, $45 \mathrm{KI} 5\left(47^{\circ} 11.5^{\prime} \mathrm{N}, 122^{\circ} 0.2 .5^{\prime} \mathrm{W}\right)$. In 1974, excavation was initiated at the Pedersen site, $45 \mathrm{KI} 4\left(47^{\circ} 11^{\prime} \mathrm{N}, 122^{\circ} 02^{\prime} \mathrm{W}\right) \mathrm{ca} .8 \mathrm{~km}$ $\mathrm{S}$ of the Jokumsen site, and are in progress. UW-254 and -255, from 2 pits dug through the flow into the soil beneath, are oldest pub dates for an archaeologic site $\mathrm{W}$ of the Cascade Mts in Washington State. UW-283, from the interface between mudflow and pre-existing soil, probably dates 
the occurrence of the mudflow. The sites were subsequently reoccupied between 3400 and $300 \mathrm{yr}$ ago (Hedlund, 1974; Hedlund, Northwest Anthropol Research Notes, in press). Coll and subm 1970-1974 by G C Hedlund, Green River Community Coll, Auburn, Washington.

Imhof subseries, 45PI44

UW-253. Z6

$445 \pm 50$

Charcoal from fire pit 28 to $43 \mathrm{~cm}$ from surface in mudflow.

UW-254. Z6

$690 \pm 85$

Charcoal assoc with fire-cracked rock and worked jasper flakes at $57 \mathrm{~cm}$ depth in mudflow.

\section{Jokumsen subseries, 45KI5}

UW-255. N2 W8 Loc 1

$\mathbf{5 7 3 0} \pm 90$

3780 вс

Charcoal assoc with leaf-shaped projectile point of red jasper at depth $1.65 \mathrm{~m}$ from surface and $56 \mathrm{~cm}$ below mudflow interface.

UW-283. N1 W2 Loc 2

$4980 \pm 60$ 3030 BC

Charcoal assoc with stone chips, flakes, and artifacts at interface of mudflow and underlying soil, $91 \mathrm{~cm}$ below surface.

UW-284. N1 W2 Loc 2

$5750 \pm 108$

Charcoal from hearth assoc with stone chipping detritus and artifacts $1.16 \mathrm{~m}$ below surface and $25.5 \mathrm{~cm}$ below mudflow interface.

\section{UW-285. N1 W1 Loc 1}

$1125 \pm 70$

Charcoal assoc with heavy cobble-sized rocks, probably an earth oven, at $75.5 \mathrm{~cm}$ depth in mudflow and above interface.

\section{UW-297. S1 W9 Loc 1}

$5035 \pm 90$

3085 BC

Charcoal assoc with many stone chips and flakes, scrapers, and 1 projectile point, at $1.34 \mathrm{~m}$ from surface and $5 \mathrm{~cm}$ below mudflow interface. Area appeared to be a hearth feature and work area.

UW-298. N9 W8 Loc 1

Modern

Wood, one of 5 posts found $48 \mathrm{~cm}$ below surface in N-S alignment, probably part of house or shed structure. Comment $(\mathrm{GCH})$ : feature is probably of Euro-American origin.

\section{UW-302. S1 W10 Loc 1}

$$
960 \pm 100
$$

\section{AD 990}

Charcoal assoc with stone chips and flakes, possibly a pit house, at $70 \mathrm{~cm}$ from surface in mudflow. 
UW-303. S1 W8 Loc 1

Charcoal assoc with stone chips and flakes in same pit as UW-302, at $60 \mathrm{~cm}$ from surface.

UW-316. S2 W10 Loc 1

$695 \pm 50$

Charcoal and carbonized wood from post 63 to $78 \mathrm{~cm}$ below surface, assoc with stone chips, a stone knife, and red-stained soil.

\section{UW-317. S1 W12 Loc 1}

$3450 \pm 80$

1500 BC

Charcoal from a hearth assoc with artifacts and chipping detritus, 63 to $78 \mathrm{~cm}$ from surface at bottom of a large house pit feature.

\section{UW-333. N2 W13 Loc 1}

$3230 \pm 60$

Charcoal from near base of house pit depression dug into mudflow at $93 \mathrm{~cm}$ from surface. Assoc with chips, flakes, and artifacts.

\section{UW-334. Pedersen site, 45KI5}

$315 \pm 55$

Charcoal from Test Pit 1 in what was probably a hearth, 45 to $58 \mathrm{~cm}$ from surface, assoc with wild cherry pits, flakes, and a blade knife.

\section{UW-38. Vantage, Washington}

$$
1070 \pm 70
$$

Charcoal from a prehistoric house pit on $\mathbf{E}$ bank of Columbia R, 45GR73, ca $22 \mathrm{~km}$ upstream from Vantage $\left(47^{\circ} 08^{\prime} \mathrm{N}, 120^{\circ} 00^{\prime} \mathrm{W}\right)$. Sample V from Housepit 11, 65cm below surface. Coll 1961 and subm by R E Greengo. Comment (REG): acceptable date for late Columbia Valley basally notched point complex.

\section{UW-68. Redmond, Washington}

$1860 \pm 110$

Charcoal from Indian house pit $\left(47^{\circ} 40^{\prime} \mathrm{N}, 122^{\circ} 07^{\prime} \mathrm{W}\right)$ 45KI9-A, Pit 27-S, Stratum 4, 90 to $110 \mathrm{~cm}$. Coll 1964 and subm by R E Greengo, Univ Washington. Comment: small sample required dilution with dead $\mathrm{CO}_{2}$ prior to methane conversion.

\section{E. Middle America}

\section{UW-118. Pololcingo, Mexico}

$2820 \pm 90$

Charcoal from Site Figueroa, $14 \mathrm{Q}$ MR 52-1, ca $1 \mathrm{~km}$ W of Pololcingo village, Guerrero State $\left(18^{\circ} 17^{\prime} \mathrm{N}, 99^{\circ} 24^{\prime} \mathrm{W}\right)$. Coll in Cut 5, 60 to $66 \mathrm{~cm}$ below surface. Site exhibits only preclassic sherds and figurine fragments on surface. Sample assoc with Tlatilco-like pumpkin-shaped bottle vessel. Coll 1967 and subm by R E Greengo. 


\section{UW-120. Santa Teresa, Mexico}

Charcoal from El Calvario site, 14Q MR41-1, on N edge of Santa Teresa village, Guerrero State $\left(18^{\circ} 14^{\prime} \mathrm{N}, 99^{\circ} 30^{\prime} \mathrm{W}\right)$. An occupation and burial site comprising at least 5 low mounds. Sample from lowest levels of highest mound, 1, combines samples from level 300 to $320 \mathrm{~cm}$ and level 320 to $340 \mathrm{~cm}$ below surface. Mound 1, ca $3 \mathrm{~m}$ high, and its vicinity have potsherds and figurines of preclassic assoc. Other parts of site have materials of both preclassic and later periods. Coll 1967 and subm by R E Greengo.

\section{F. South America}

\section{Guayaquil series, Ecuador}

The following 3 samples are from the old hacienda La Atarazana on the $\mathrm{N}$ perimeter of Guayaquil $\left(01^{\circ} 10^{\prime} 48^{\prime \prime} \mathrm{N}, 79^{\circ} 53^{\prime} 40^{\prime \prime} \mathrm{W}\right)$. The middens, only ca $1 \mathrm{~m}$ deep, are on a bank leading down to a salt marsh, since closed off by urban development. Samples relate to Regional Developmental period, ca 300 to 400 BC. Coll 1967 by R \& I Parducci, Mus House of Ecuadorian Culture, Guyayaquil; subm by R E Greengo.

UW-123. Cut M

Oyster shells found near sherds of pottery, depth $60 \mathrm{~cm}$.

\section{UW-124. Cut G}

Charcoal from deepest stratum in deposit, depth $80 \mathrm{~cm}$.

\section{UW-125. Cut E}

Charcoal from $60 \mathrm{~cm}$ depth.

\section{GEOLOGIC SAMPLES}

\section{A. Western United States}

$2175 \pm 60$

$225 \mathrm{BC}$

$2185 \pm 80$

235 BC

\section{Portland, Oregon series}

The following 5 samples of carbonized wood fragments were obtained from borehole drillings: UW-310 and -311 are from a borehole in scoria of Boring Basalt atop West Hills near corner of SW Barnes and Miller $\mathrm{Rd}\left(45^{\circ} 31^{\prime} \mathrm{N}, 122^{\circ} 45^{\prime} \mathrm{W}\right)$. These dates indicate that Boring Basalt volcanism occurred $>40,000 \mathrm{yr}$ ago, and that at least part of the volcanic deposits in this area was covered by sediments at that time. UW-914 is from a borehole at a dock along the $\mathrm{W}$ bank of the Willamette River $\mathrm{N}$ of Linnton (45 $\left.36^{\prime} 28^{\prime \prime} \mathrm{N}, 122^{\circ} 47^{\prime} 12^{\prime \prime} \mathrm{W}\right)$. UW-312 and -315 are from another borehole nearby on the bank $\left(45^{\circ} 36^{\prime} 34^{\prime \prime} \mathrm{N}, 122^{\circ}\right.$ $\left.47^{\prime} 19^{\prime \prime} \mathrm{W}\right)$. These 3 samples reveal the young age of sediments filling the Portland basin (Hammond, $\mathrm{ms}$ in preparation). We can assume that either, 1) the Portland basin has been subsiding during the past 5000 
yr or more, or 2) that sea level, hence, the levels of the Columbia and Willamette Rivers, have been rising during the same period of time, or 3) the sediments have been compacting. From differences in alt and ages between samples, we infer that rate of sediment accumulation and/or subsidence in the area is $\mathrm{ca} .4 \mathrm{~cm} / \mathrm{yr}$ (Hammond, 1975). Coll and subm 1974 by P E Hammond, Portland State Univ.

UW-310. B1, SS-11, wood $>40,000$

From gray silt, at 9.1 to $9.6 \mathrm{~m}$ depth in borehole, at ca $+222.5 \mathrm{~m}$.

UW-311. B1, SS-12, wood

$>40,000$

From dark scoria (Boring Basalt), at 10.7 to $11.1 \mathrm{~m}$ depth in same borehole as above.

UW-312. ZTE-8-15, charcoal

$6490 \pm 100$

From thin volcanic ash, tentatively id as Mazama ash, at 22.1 to $22.6 \mathrm{~m}$ depth in borehole, at ca $-13 \mathrm{~m}$. Date of Mazama eruption has been placed at $6600 \mathrm{BP}$ (Fryxell, 1965) and $7000 \mathrm{BP}$ (Kittleman, 1973). Small sample size required the minicounter.

UW-314. ZTE-13-2, wood

$4800 \pm 90$

From gray silt at 14.5 to $14.9 \mathrm{~m}$ depth in borehole at ca $-5.8 \mathrm{~m}$.

2850 BC

$5420 \pm 100$

UW-315. ZTE-8-12, charcoal

$\mathbf{3 4 7 0} \mathrm{BC}$

From gray silt at 17.5 to $18 \mathrm{~m}$ depth in same borehole as UW-312, at ca $-8.4 \mathrm{~m}$.

\section{UW-309. Trout Lake, Washington}

$>40,000$

Charcoal in crossbedded fluvial basaltic sandstone underlying Skull Creek Point Basalt. Age is minimum for lava flow. Coll and subm 1974 by $\mathrm{P}$ E Hammond.

\section{Cascade Range series, Washington}

UW -66. Ronald, Washington

$37,500 \pm 2800$

35,500 BC

Charcoal from eolian silt beneath Bullfrog Till on $\mathrm{E}$ bank of Cle Elum R, 2.7km S of Ronald, Washington $\left(47^{\circ} 13^{\prime} \mathrm{N}, 121^{\circ} 01^{\prime} \mathrm{W}\right)$. Coll and subm 1964 by S C Porter, Univ Washington. Comment (SCP): sample probably contaminated with Eocene coal. A duplicate sample was dated $>37,000($ I-1717, unpub).

\section{UW-116. Mt Baker, Washington} AD 1820

$130 \pm 40$

Wood from cutbank in Lateral Moraine II of E Nooksack Glacier $\left(48^{\circ} 50.6^{\prime} \mathrm{N}, 121^{\circ} 33.2^{\prime} \mathrm{W}\right.$ ) ca $1.3 \mathrm{~m}$ from top of moraine. Coll and subm 1967 by S C Porter. 


\section{Snoqualmie Pass series, Washington}

The following 3 samples were coll in and beneath a bog resting on Hyak drift at Snoqualmie Pass, Washington $\left(47^{\circ} 29.5^{\prime} \mathrm{N}, 121^{\circ} 24.9^{\prime} \mathrm{W}\right)$.

\section{UW-73. Snoqualmie Pass, Washington}

$7200 \pm 210$

Charcoal from basal peat, directly beneath Mazama ash. Minimum date for Hyak drift. Coll and subm 1964 by S C Porter.

\section{UW-322. Snoqualmie Pass, Washington}

$7450 \pm 70$

Wood at base of bog. Coll and subm 1974 by S C Porter.

\section{UW-321. Snoqualmie Pass, Washington}

Wood in late-Hyak gravel. Age is minimum for Hyak readvance. Coll and subm 1974 by S C Porter.

\section{Olympic Peninsula series, Washington}

The following 4 samples, all of the same age, are $1400 \mathrm{yr}$ too young to have been incorporated in glacial drift by last glacial advance into the Puget Lowland. The anomaly has been attributed to a forest invasion of debris-mantled stagnant ice remaining after general ice recession. Subsequent melting and collapse of the superglacial terrain incorporated the younger trees into the glacial drift (Porter and Carson, 1971).

\section{UW-144. Lake Dickey, Washington}

$12,660 \pm 220$

Wood from Fraser till in roadcut $4 \mathrm{~km} \mathrm{~S}$ of Lake Dickey $\left(48^{\circ} 03.3^{\prime}\right.$ N, 124 28' W). Coll 1969 D Biederman; subm S C Porter.

\section{UW-146A. Simpson Lake, Washington}

Wood from a complex diamicton of late Fraser age exposed on $\mathrm{N}$ side of small hill immediately S of Simpson Lake $\left(47^{\circ} 7.8^{\prime} \mathrm{N}, 123^{\circ} 20.2^{\prime}\right.$ $\mathrm{W})$ and $<1 \mathrm{~km}$ from drift border. Coll and subm 1969 by R J Carson, III.

\section{$12,430 \pm 160$ Duplicate of above. \\ $10,480 \mathrm{BC}$ \\ $12,620 \pm 150$ \\ UW-147. Simpson Lake, Washington \\ $10,670 \mathrm{BC}$}

Wood from same formation as UW-146A. A piece measured as a cross check by the Rudjer Boskovic Inst (R, 1971, v 13, p 138) gave 12,700 \pm 200 вP. Coll and subm 1969 by R J Carson, III. 


\section{B. Alaska}

\section{Chagvan Bay series, Alaska}

The following 4 samples are from bases of lacustrine sediments exposed in a sea cliff $\mathrm{N}$ of the mouth of the Salmon $\mathrm{R}$ near Platinum, Alaska. Peat directly overlies iron-stained glacial drift and dates a minimum age for 2 glaciations (Porter, 1967). Coll and subm 1963 by S C Porter.

UW-56. Salmon River

$8910 \pm 110$

Peat from bog $9 \mathrm{~km} \mathrm{~N}$ of river mouth $\left(58^{\circ} 53.4^{\prime} \mathrm{N}, 161^{\circ} 46.9^{\prime} \mathrm{W}\right)$.

\section{UW-57. Salmon River}

Peat from bog $2.6 \mathrm{~km} \mathrm{~N}$ of river mouth $\left(58^{\circ} 53^{\prime} \mathrm{N}, 161^{\circ} 46.8^{\prime} \mathrm{W}\right)$.

\section{UW-70. Salmon River}

$12,830 \pm 160$

Peat from bog $1.9 \mathrm{~km} \mathrm{~N}$ of river mouth ( $\left.58^{\circ} 52.7^{\prime} \mathrm{N}, 161^{\circ} 46.7^{\prime} \mathrm{W}\right)$.

$$
10,880 \mathrm{BC}
$$

UW-71. Salmon River

$12,070 \pm 140$

Peat from bog $2.1 \mathrm{~km} \mathrm{~N}$ of river mouth $\left(58^{\circ} 52.8^{\prime} \mathrm{N}, 161^{\circ} 46.7^{\prime} \mathrm{W}\right)$.

\section{Icy Bay series, Alaska}

Wood incorporated in Neoglacial drift along shore of Icy Bay records last advance of Icy Bay glacier to a point beyond mouth of bay (Post, in press). Coll and subm 1972 by S C Porter.

UW-267. Guyot Hills

Modern

Outer rings of limb from Neoglacial till $\left(60^{\circ} 08.8^{\prime} \mathrm{W}, 141^{\circ} 27.7^{\prime} \mathrm{W}\right)$. Dates advance of Icy Bay glacier.

UW-268. Clayey Bluff

$$
325 \pm 40
$$

Bark from $\log$ in situ at Clayey Bluff on SW shore of Icy Bay ca $.8 \mathrm{~km} \mathrm{NE}$ of logging camp $\left(59^{\circ} 59.5^{\prime} \mathrm{N}, 141^{\circ} 30.2^{\prime} \mathrm{W}\right)$. Dates last advance of Icy Bay glacier.

\section{UW-269. Pt Rion}

Modern

Log embedded in Neoglacial till $2 \mathrm{~km} \mathrm{E}$ of Pt Rion on SE shore of Icy Bay $\left(59^{\circ} 52.2^{\prime} \mathrm{N}, 141^{\circ} 25.9^{\prime \prime} \mathrm{W}\right)$.

\section{Hawaiian Islands}

\section{Mauna Kea series, Hawaii}

Sub-series 1. The lower S slope of Mauna Kea is blanketed by midHolocene tephra that represents latest major eruptions of the volcano. A widespread buried soil (Humuula Soil) contains locally abundant charcoal (Porter, 1971; 1973; 1975). 
UW-165. Humuula Sheep Station

Charcoal from Humuula Soil, .5km E of Humuula Sheep Sta $\left(190^{\circ}\right.$ $\left.42.1^{\prime} \mathrm{N}, 155^{\circ} 27.4^{\prime} \mathrm{W}\right)$. Coll and subm 1970 by S C Porter.

\section{UW-166. Puu Huikau}

Charcoal from top of Humuula Soil under Puu Kole tephra in gully on W side of Keanakolu Rd, .8km N Puu Huikau, alt $2158 \mathrm{~m}\left(19^{\circ} 43.4^{\prime}\right.$ N, $\left.155^{\circ} 26.6^{\prime} \mathrm{W}\right)$. Coll and subm 1970 by S C Porter.

\section{UW-188. Humuula Sheep Sta}

Charcoal from buried soil, .5km E of Hale Pohaku Rd, alt $2020 \mathrm{~m}$ $\left(19^{\circ} 42.1^{\prime} \mathrm{N}, 155^{\circ} 27.5^{\prime} \mathrm{W}\right)$. Coll and subm 1971 by S C Porter.

Sub-series 2. Charcoal fragments contained in surface soil at various points around mountain record widespread fires near timberline. Coll and subm 1971 by S C Porter.

\section{UW-189. Loc 112}

$$
570 \pm 70
$$

Charcoal from fire-reddened zone in soil overlying weathered ash beds $\left(19^{\circ} 45.0^{\prime} \mathrm{N}, 155^{\circ} 22.8^{\prime} \mathrm{W}\right)$.

\section{UW-214. Loc 292}

$$
\text { AD } 1870
$$

$$
80 \pm 60
$$

Charcoal from fire-reddened zone in roadcut overlying $3 \mathrm{~m}$ weathered bedded ash on $\mathrm{N}$ side of Mauna Kea near Makahalau $\left(19^{\circ} 57.6^{\prime} \mathrm{N}, 155^{\circ}\right.$ $\left.31.2^{\prime} \mathrm{W}\right)$.

\section{UW-215. Kemole Cabin}

$$
2190 \pm 50
$$

\section{Charcoal from 30 to $40 \mathrm{~cm}$ benea} colluvial/alluvial fil just below Kemole Cace in modern solum. Caps Kea $\left(19^{\circ} 52.9^{\prime} \mathrm{N}, 155^{\circ} 32.2^{\prime} \mathrm{W}\right)$.

Sub-series 3. 3 old tephra layers on W rift zone of volcano underlie eolian sand of last glacial age and overlie eolian sand of earlier glaciation. Charcoal intercalated with tephra layers limits ages of the 2 glaciations (Porter, in press). Coll and subm 1971 by S C Porter.

\section{UW-213. Saddle Rd}

$29,700 \pm 500$

Charcoal underlying uppermost of 3 tephra layers on Saddle Rd, alt $1660 \mathrm{~m}\left(19^{\circ} 50.2^{\prime} \mathrm{N}, 155^{\circ} 38.6^{\prime} \mathrm{W}\right)$.

\section{UW-219. Saddle Rd}

$37,200 \pm 1400$ 35,250 BC

Charcoal underlying lowermost tephra layer on Saddle $\mathrm{Rd}$, at alt $1650 \mathrm{~m}\left(19^{\circ} 50.2^{\prime} \mathrm{N}, 155^{\circ} 38.6^{\prime} \mathrm{W}\right)$. 
UW-220. Saddle Rd

$\mathbf{3 1 , 9 0 0} \pm \mathbf{5 5 0}$

Charcoal between lower and middle tephra layers on Saddle $\mathrm{Rd}$ at alt $1650 \mathrm{~m}\left(19^{\circ} 50.2^{\prime} \mathrm{N}, 155^{\circ} 38.6^{\prime} \mathrm{W}\right)$.

UW-197. Mauna Kea

$$
\begin{gathered}
\text { Modern } \\
\delta^{14} \mathbf{C}=\mathbf{0} \pm \mathbf{5} \% \text { o }
\end{gathered}
$$

Shells (Patella) from adze quarry $\left(19^{\circ} 47.5^{\prime} \mathrm{N}, 155^{\circ} 28.2^{\prime} \mathrm{W}\right)$.

\section{UW-270. Nohonaohae cinder cone}

$22,150 \pm 250$

Charcoal in silt below cinder layer from Nohonaohae cinder cone $\left(19^{\circ} 57.1^{\prime} \mathrm{N}, 155^{\circ} 41.4^{\prime} \mathrm{W}\right)$. Dates latest eruptive phase on lower NW rift of Mauna Kea. Coll and subm 1972 by S C Porter.

\section{UW-271. Mauna Kea}

Charcoal underlying buried soil developed in alluvium and overlain by loess on lower NW rift zone of Mauna Kea, alt $1320 \mathrm{~m}\left(19^{\circ} 50.3^{\prime} \mathrm{N}\right.$, $155^{\circ} 40.2^{\prime} \mathrm{W}$ ). Dates aggradational interval. Coll and subm 1972 by S C Porter.

\section{E Norway series}

\section{Europe}

The following samples are from 8 peat bogs in $\mathrm{E}$ Norway, the sites of which range from Magnor in the $\mathrm{S}$ to Roros in the $\mathrm{N}$, ca $300 \mathrm{~km}$ distance. Dates are fairly consistent with general chronology of region, based on other radiocarbon dates and postglacial vegetational succession as determined by pollen analyses of these and many other secs by other workers. The 8 bogs are among 25 secs in the same region, analyzed for pollen and interpretation of vegetational record. A maximum age of 9400 yr was determined by dating other samples at the Radiological Dating Lab, Trondheim, Norway. Coll and subm 1971 by H P Hansen, Oregon State Univ.

\section{UW-225. Magnor}

$8460 \pm 90$

$6510 \mathrm{BC}$

$\delta^{13} \mathrm{C}=-28.5 \%$

Clay from base of bog, depth $6.25 \mathrm{~m}\left(59^{\circ} 57^{\prime} \mathrm{N}, 12^{\circ} 15^{\prime} \mathrm{E}\right)$. Pine predominant, with birch and grass; Early Boreal age.

UW-226. Tangen

$$
\begin{gathered}
8560 \pm 90 \\
6610 \mathrm{BC} \\
\delta^{13} C=-28.5 \%
\end{gathered}
$$

Clay from base of bog, depth $12 \mathrm{~m}, 8 \mathrm{~km} \mathrm{SE}$ of Tangen $\left(60^{\circ} 37^{\prime} \mathrm{N}\right.$, $11^{\circ} 39^{\prime}$ E). Pine predominant with birch and hazel; probably Early Boreal age.

\section{UW-231. Lillehammer}

$8200 \pm 100$

Clay from base of bog, depth $2.5 \mathrm{~m}, 14 \mathrm{~km} \mathrm{NE}$ of Lillehammer $\left(61^{\circ}\right.$ $\left.09^{\prime} \mathrm{N}, 10^{\circ} 40^{\prime} \mathrm{E}\right)$. Pine predominant with birch and grass; probably 
Boreal age. Comment $(\mathrm{HPH})$ : date is rather high considering shallow depth of bog and alt $850 \mathrm{~m}$. Depth can be attributed to slow rate of organic sedimentation at this alt but magnitude of date in relation to the time of deglaciation is significant.

\section{UW-232. Elverum}

$7420 \pm 150$

Clay from base of bog, depth $6 \mathrm{~m}, 6 \mathrm{~km}$ W of Elverum $\left(60^{\circ} 50^{\prime} \mathrm{N}\right.$, $15^{\circ} 28^{\prime}$ E). Pine, birch, and alder; Late Boreal age. Small sample size required minicounter.

\section{UW-239. Tynset}

$7760 \pm 90$ 5810 вC

Clay from base of bog, depth $3 \mathrm{~m}, 10 \mathrm{~km} \mathrm{~S}$ of Tynset $\left(62^{\circ} 1 \mathrm{l}^{\prime} \mathrm{N}\right.$, $\left.10^{\circ} 46^{\prime} \mathrm{E}\right)$. Pine predominant with birch, alder, and grass; Late Boreal age.

\section{UW-244. Tynset}

$5710 \pm 90$ $\mathbf{3 7 6 0 ~ B C}$

Wood from same bog as UW-239, depth $2 \mathrm{~m}$. Pine predominant with birch and alder; early Sub-Boreal age.

\section{UW-245. Roros}

$7210 \pm 100$

Clay from base of bog, depth $3.5 \mathrm{~m}, 25 \mathrm{~km} \mathrm{NE}$ of Roros $\left(62^{\circ} 36^{\prime} \mathrm{N}\right.$, $11^{\circ} 32^{\prime}$ E). Pine predominant, with birch; Atlantic age. Small sample size required minicounter.

\section{UW-246. Amot}

$7125 \pm 120$

$5175 \mathrm{BC}$

Limnic peat from base of bog, depth $4.3 \mathrm{~m}, 15 \mathrm{~km} \mathrm{NE}$ of Amot $\left(61^{\circ}\right.$ $\left.11^{\prime} \mathrm{N}, 11^{\circ} 11^{\prime} \mathrm{E}\right)$. Pine and alder predominant with birch; Atlantic age.

\section{UW-247. Amot}

$6480 \pm 110$

Wood from same bog as UW-246, depth $3.2 \mathrm{~m}$. Pine predominant with birch, alder, and grass; Late Atlantic age.

\section{UW-248. Arneberg}

$7625 \pm 110$ 5675 BC

Clay from base of bog, depth $5 \mathrm{~m}, 16 \mathrm{~km}$ SE of Arneberg $\left(60^{\circ} 14^{\prime} \mathrm{N}\right.$, $\left.12^{\circ} 07^{\prime} \mathrm{E}\right)$. Pine predominant with birch and hazel; Boreal age. Small sample size required minicounter.

\section{REFERENCES}

Buddemeier, R W, Young, A W, Fairhall, A W, and Young, J A, 1970, Improved system of methane synthesis for radiocarbon dating: Rev Sci Inst, v 41, p 652-654. Butzer, K W, 1973, Geology of Nelson Bay Cave, Robberg, South Africa: South African Archaeol Bull, v 28, p 97-110.

Camps, G, 1974, Les civilisations prehistoriques d l'Afrique du Nord et du Sahara: Paris, Doin.

Crandell, D R, 1963, Surficial geology and geomorphology of the Lake Tapps quadrangle, Washington: U S Geol Survey Prof Paper 388-A, p Al-A84.

Deacon, H J, 1969, Melkhoutboom Cave, Alexandria District, Cape Province: a report on the 1967 investigation: Annals Cape Prov Mus (Nat Hist), v 6, p 141-169. 
Deacon, H J, 1972, A review of the post-Pleistocene in South Africa: South African Archaeol Soc Goodwin ser, v 1, p 26-45.

1974, An archaeological survey of the Eastern Cape in the Post-Pleistocene period: Unpub PhD dissertation, Univ Cape Town, South Africa.

Fairhall, A W and Young, A W, 1973, Radiocarbon dates from Nelson Bay Cave: South African Archaeol Bull, v 28, p 90-93.

Fryxell, Roald, 1965, Mazama and Glacier Peak volcanic ash layers-Relative ages: Science, v 147, no. 3663, p 1288-1290.

Hammond, P E, 1975, Some radiocarbon dates in surficial deposits of the Portland area: Ore Bin, v 37, p 161-172.

Hedlund, G C, 1974, Current Research: Am Antiquity, v 39, p 628. 1975, Current Research: Am Antiquity, v 40, p 479.

Kittleman, L R, 1973, Mineralogy, correlation, and grain-size distributions of Mazama tephra and other post-glacial pyroclastic layers, Pacific Northwest: Geol Soc America Bull, v 84, p 2957-2980.

Klein, R G, 1972a, Preliminary report on the July through September 1970 excavations at Nelson Bay Cave, Plettenberg Bay (Cape Province, South Africa): Paleoecol Africa, v 6, p 177-208.

1972b, The late Quaternary mammalian fauna of Nelson Bay Cave (Cape Province, South Africa): its implications for megafaunal extinctions and for environmental and cultural change: Quaternary Research, v 2, p 135-142.

1974a, Environment and subsistence of prehistoric man in the Southern Cape Province, South Africa: World Archaeol, v 5, p 249-284.

$1974 \mathrm{~b}$, A provisional statement on terminal Pleistocene mammalian extinctions in the Cape Biotic Zone (southern Cape Province, South Africa): South African Archaeol Soc Goodwin ser, v 2, p 39-45.

Maître, J P, 1971, Contribution à la Préhistoire de l'Ahaggar. I. Tefedest Centrale: Paris, Arts et Metiers Graphiques.

1974, Perspectives nouvelles sur la Préhistoire récènte de l'Ahaggar. Libyca, $\mathrm{v}$ XXII, in press.

1975, Contribution à la Préhistoire récènte de l'Ahaggar dans son contexte saharien: $m s$ in preparation.

Parkington, J E, 1972, Seasonal mobility in the Later Stone age: African Studies, v 31, p 223-243.

Porter, S C, 1967, Glaciation of Chagvan Bay area, Southwestern Alaska: Arctic, v 20, p $227-246$

1971, Holocene eruptions of Mauna Kea volcano, Hawaii: Science, v 172, p 375-377.

1973, Stratigraphy and chronology of late Quaternary tephra along the South Rift zone of Mauna Kea Volcano, Hawaii: Geol Soc America Bull, v 84, p 1923-1940.

1975 , Late Quaternary glaciation and tephrochronology of Mauna Kea, Hawaii: Roy Soc New Zealand Bull, v 13, p 247-251.

Porter, S C and Carson, R J, 1971, Problems of interpreting radiocarbon dates from deadice terrain, with an example from the Puget Lowland of Washington: Quaternary Research, v 1, p 410-414.

Schweitzer, F R, 1970, A preliminary report of excavations of a cave at Die Kelders: South African Archaeol Bull, v 99 \& 100, p 136-138. p $75-82$.

1974, Archaeological evidence for sheep at the Cape: Ibid, v 115 \& 116,

Schweitzer, F R and Scott, K, 1973, Early occurrence of domestic sheep in sub-Saharan Africa: Nature, v 241, p 547.

Watson, Virginia and Cole, J D, Prehistory of the Eastern Highlands of New Guinea, in: Watson, J B (ed), Anthropological studies in the Eastern Highlands of New Guinea: Seattle, Univ Washington Press, in press. 